\title{
MICROWAVE MANUFACTURE OF GLASS FOAM BY COMBINED USE OF GRAPHITE AND CALCIUM CARBONATE AS FOAMING AGENTS
}

\author{
LUCIAN PAUNESCU ${ }^{* 1}$, SORIN MIRCEA AXINTE ${ }^{1,2}$, MARIUS FLORIN \\ DRAGOESCU ${ }^{2}$, BOGDAN VALENTIN PAUNESCU ${ }^{3}$, FELICIA COSMULESCU ${ }^{4}$ \\ ${ }^{1}$ Daily Sourcing \& Research SRL, 95-97 Calea Grivitei, sector 1, Bucharest 010705, Romania \\ ${ }^{2}$ University "Politehnica” of Bucharest, Faculty of Applied Chemistry and Materials \\ Science, 1-7 Gh. Polizu street, sector 1, Bucharest 011061, Romania \\ ${ }^{3}$ Consitrans SA, 56 Polona street, sector 1, Bucharest 010504, Romania \\ ${ }^{4}$ Cosfel Actual SRL, 95-97 Calea Grivitei, sector 1, Bucharest 010705, Romania
}

\begin{abstract}
The paper presents experimental results obtained in the manufacturing process of high-strength glass foam by combined use of two solid foaming agents (calcium carbonate and graphite) in variable weight ratios. The originality of the work is applying the unconventional microwave heating method, unlike the conventional techniques currently used in similar industrial processes. The optimal experimental variant, composed of $89.1 \%$ glass waste, $0.9 \%$ calcium carbonate, $1 \%$ graphite and other additives, was sintered at 828 ${ }^{\circ} \mathrm{C}$ with a very low energy consumption $(0.73 \mathrm{kWh} / \mathrm{kg})$. The main characteristics of the optimal product were apparent density of $0.39 \mathrm{~g} / \mathrm{cm}^{3}$, thermal conductivity of $0.088 \mathrm{~W} / \mathrm{m} \cdot \mathrm{K}$ and compressive strength of $3.6 \mathrm{MPa}$, being usable in fields that requires resistance to mechanical stress and relatively difficult environmental conditions.
\end{abstract}

Keywords: glass foam, colorless packaging bottle, microwave heating, calcium carbonate, graphite, low energy consumption

\section{INTRODUCTION}

In recent decades, the recycling of waste (plastic, metal, glass, paper, etc.) and industrial by-products (metallurgical slag, coal ash, sludge, oil shale, etc.) [1] has become one of the priority concerns especially of developed countries and those developing. The annual rate of generating this waste is constantly increasing, so storing it is no longer a viable solution. In this context, only the reintroduction of waste and by-products in the industrial manufacturing process of new products of the same type is no longer a sufficient solution in terms of ecology, being necessary new variants of their valorization.

The glass industry, whose basic products have relatively short durations of use, generates large amounts of waste (25.8 Mt in EU in 2007) [2], which is an ecologically major problem. In Romania, an annual growth rate of glass waste reserves is estimated at several hundred thousand tons [3]. In addition, the wide range of glass assortments with different chemical composition makes their sorting operation difficult and expensive for the reintroduction into the circuit of industrial glass production. In the last decades, it has been found that the building materials

\footnotetext{
* Corresponding author, email: lucianpaunescu16@gmail.com

(C) 2021 Alma Mater Publishing House
} 
industry, that is a great consumer of fossil fuels and a greenhouse gases generator [2], could assimilate similar products made of glass waste with much lower energy consumption (about $500 \mathrm{~kJ} / \mathrm{kg}$ ) than that required for the manufacture of glass (about $1500 \mathrm{~kJ} / \mathrm{kg}$ ) [4]. Consequently, several facilities of industrial-scale manufacturing companies (Misapor, Pittsburgh Corning, Geocell Schaumglass, Glapor Werk Mitterteich, etc.) already operate in Europe, the United States and China. Various types of glass foam, light porous products with very good thermal insulation properties and with mechanical strength at least acceptable or relatively high, having similar characteristics to those of building materials existing on the market are manufactured industrially [5]. Also, experimental research in the field of quality improvement and expansion of the range of glass waste products is very active in the world, the literature providing numerous examples.

Currently, the basic principle of the manufacture of a glass foam is the incorporation into the finely ground mass of glass-based raw material of a solid or liquid foaming agent, which releases a gas or gaseous compound as a result of a chemical reaction at high temperature (above $750-800{ }^{\circ} \mathrm{C}$ ) in accordance with the softening temperature of raw material. This technique favors the formation of gas bubbles in the viscous mass of the material, which remain trapped there and by cooling at the end of the heating process generates a porous structure specific to glass foam. During the foaming process, gaseous products are generated by decomposition or redox reactions [6]. Generally, the decomposition reactions of carbonates forms $\mathrm{CO}_{2}$ gas and the metal oxides are embedded into the molten glass modifying its characteristics [7, 8]. In the case of oxidation of pure carbon or some carbon compounds (graphite, coke, anthracite, carbon black, glycerol, etc.), no solid residuals result and the oxygen necessary for the process is taken from the oven atmosphere air and the glass network [9].

According to the literature (generally, booklets and technical documentations of the main industrial producers), one of the preponderantly used foaming agents in industrial manufacturing processes of glass foam is carbon or carbon containing compounds mentioned above. For manufacturing the "Foamglas" product in the form of thermal insulation blocks for building insulation or as thermal insulation aggregates, Pittsburgh Corning Company uses carbon black as a foaming agent and to produce TECHNOpor product in the form of highstrength thermal insulation panels or insulation aggregates under mechanical stress conditions, Misapor company also uses carbon black. The same company uses separately gypsum $\left(\mathrm{CaSO}_{4}\right)$, calcium carbonate $\left(\mathrm{CaCO}_{3}\right)$ or silicon carbide ( $\mathrm{SiC}$ ) to make foam glass gravel (FGG). One of the specialized companies on FGG manufacturing, Glapor Werk Mitterteich uses a liquid carbonic foaming agent (glycerol) together with sodium silicate as an enveloping agent. The German company Glamaco, supplier of ovens and equipment for the industrial manufacture of glass foam, recommends $\mathrm{SiC}$, manganese oxide $\left(\mathrm{MnO}_{2}\right), \mathrm{CaCO}_{3}$, coal powder (or soot), glycerol, gypsum and for the manufacture of $\mathrm{FGG}$, glycerol and $\mathrm{CaCO}_{3}$ simultaneously, together with sodium silicate [10]. Therefore, carbon-based foaming agents, cheaper and with a strong tendency to oxidize at lower temperatures $\left(800-900{ }^{\circ} \mathrm{C}\right)$ compared to other foaming agents, are the most suitable for the foaming process of glass waste. In general, glass foam made in this way has low pore sizes. The recommended addition of carbon foaming agent is between $0.2-2.0 \mathrm{wt} . \%$ [6].

Due to the peculiarities of carbon as a foaming agent, its use in oven without oxidizing atmosphere is difficult, being necessary the introduction of materials with the role of enveloping the fine carbon particles to prevent its premature oxidation [11]. Small-scale experiments have shown that alkaline phosphates (especially, sodium phosphate- $\mathrm{Na}_{3} \mathrm{PO}_{4}$ and potassium phosphate- $\left.\mathrm{K}_{3} \mathrm{PO}_{4}\right)$ used in foaming processes of glass waste have a role of foam stabilizer [12]. The transition temperature $\left(\mathrm{T}_{\mathrm{g}}\right)$ of soda-lime silicate glass waste decreased with increasing the alkaline phosphate content, showing that the foaming process temperature can be reduced. $\mathrm{Na}_{3} \mathrm{PO}_{4}$ and $\mathrm{K}_{3} \mathrm{PO}_{4}$ have been identified as suitable for foaming processes, the manufactured glass foam having low apparent density values.

According to König et al. (2014) [13], the kinetics of the $\mathrm{CaCO}_{3}$ decomposition as a foaming agent in glass waste has a great influence on the foaming process. By increasing the grinding time of the glass- $\mathrm{CaCO}_{3}$ mixture and reducing its pore size, the temperature of the decomposition process and implicitly, foaming the raw material can be reduced, the apparent density and thermal conductivity of the foamed product reaching low values of 0.26 $\mathrm{g} / \mathrm{cm}^{3}$ and $0.050-0.053 \mathrm{~W} / \mathrm{m} \cdot \mathrm{K}$, respectively.

A technique of foaming a cathode-ray tube (CRT) panel glass waste using charcoal (a lightweight carbon black residue) as a foaming agent and $\mathrm{MnO}_{2}$ as an oxygen supplier for $\mathrm{CO}_{2}$ release was presented in 2015 by König at al. [14]. The carbon and $\mathrm{MnO}_{2}$ particle sizes as well as the weight proportion of $\mathrm{MnO}_{2}$ significantly influence the apparent density of the foamed material. These sizes between 15 and $27 \mu \mathrm{m}$ facilitate density values between $0.18-0.25 \mathrm{~g} / \mathrm{cm}^{3}$ at foaming temperatures in the range $800-840{ }^{\circ} \mathrm{C}$. The optimal final sample 
obtained by sintering at $800{ }^{\circ} \mathrm{C}$, using 1 wt.\% carbon and 5.4-7.2 wt.\% $\mathrm{MnO}_{2}$, had an apparent density of 0.13 $\mathrm{g} / \mathrm{cm}^{3}$ and a thermal conductivity of $0.042 \mathrm{~W} / \mathrm{m} \cdot \mathrm{K}$.

The foaming processes mentioned above, carried out in industrial ovens or tested on a small experimental scale were performed by traditional conventional heating techniques. The team of paper's authors also performed several experiments using the mentioned foaming agent types, under the conditions of applying the unconventional microwave heating technique $[10,15,16]$. Known in principle since the middle of the $20^{\text {th }}$ century, this advanced technique is industrially used to a small extent only in drying processes or in low temperature heating processes of solids, although it is known to be fast and economical and several material types (ceramics, polymers, organics, glasses, metals, etc.) are suitable to be efficiently microwave heated [17].

An experiment close to the type of research revealed in the present paper was recently conducted by the same team of researchers [18] aiming at the activated carbon foaming of a borosilicate glass waste using the microwave energy. A weight proportion of $1 \mathrm{wt} . \%$ activated carbon as a foaming agent, $6.2 \mathrm{wt} . \%$ of disodium phosphate $\left(\mathrm{Na}_{2} \mathrm{HPO}_{4}\right)$ as a foam stabilizer and a water addition of $10 \mathrm{wt} . \%$ to facilitate the cold pressing of the powder mixture were incorporated and mixed into the borosilicate glass waste powder $(92.8$ wt. $\%)$ as raw material. The sintering/foaming temperature was $820^{\circ} \mathrm{C}$, the average heating rate being $15.3{ }^{\circ} \mathrm{C} / \mathrm{min}$. The foamed product characteristics were apparent density of $0.34 \mathrm{~g} / \mathrm{cm}^{3}$, porosity of $84.5 \%$, thermal conductivity of 0.055 $\mathrm{W} / \mathrm{m} \cdot \mathrm{K}$, compressive strength of $2.5 \mathrm{MPa}$ and pore size between $1.0-2.5 \mathrm{~mm}$.

Several experiments on manufacturing process of foam glass gravel were carried out in microwave field using glycerol as a liquid carbonic foaming agent [10]. The comparative analysis of the tested variants led to the conclusion that the best sample of foam glass gravel was that made of $83 \mathrm{wt} \%$ colorless glass waste, $1 \mathrm{wt} \%$ glycerol, 8 wt.\% sodium silicate and 8 wt. $\%$ water by heating to $823{ }^{\circ} \mathrm{C}$ with a low energy consumption of 0.88 $\mathrm{kWh} / \mathrm{kg}$. The sample characteristics were: apparent density of $0.24 \mathrm{~g} / \mathrm{cm}^{3}$, porosity of $89.1 \%$ with pore size between $0.3-0.6 \mathrm{~mm}$, thermal conductivity of $0.063 \mathrm{~W} / \mathrm{m} \cdot \mathrm{K}$, compressive strength of $5.9 \mathrm{MPa}$ and water absorption of $0.6 \%$.

The microwave heating was also used in the current work, being tested a foaming process of glass waste in which graphite and calcium carbonate $\left(\mathrm{CaCO}_{3}\right)$ were simultaneously incorporated into the starting powder mixture in variable weight ratios in order to obtain a glass foam with a significant improvement of the mechanical strength. An almost similar process performed by a conventional heating technique (in a muffle oven) using glass waste, quartz, barite $\left(\mathrm{BaSO}_{4}\right)$ as raw material, borax $\left(\mathrm{Na}_{2} \mathrm{~B}_{4} \mathrm{O}_{7} \cdot 10 \mathrm{H}_{2} \mathrm{O}\right)$ as a fluxing agent, graphite and $\mathrm{CaCO}_{3}$ as foaming agents was recently presented in the literature [19]. Glass foam with optimal characteristics was obtained with $1 \mathrm{wt} . \%$ graphite and $2 \mathrm{wt} . \% \mathrm{CaCO}_{3}$ at a sintering temperature of $850{ }^{\circ} \mathrm{C}$. The thermal conductivity of the product was $0.066 \mathrm{~W} / \mathrm{m} \cdot \mathrm{K}$ and the mechanical performance was improved over 2 times. The simultaneous use of graphite and $\mathrm{CaCO}_{3}$ as foaming agents showed that by increasing the $\mathrm{CaCO}_{3} /$ graphite ratio from 0 to 3 (the weight proportion of graphite being $1 \mathrm{wt} . \%$ in the powder mixture) the proportion of closed porosity of the foamed product significantly decreased from about $80 \%$ to $22 \%$ (in the case of foaming temperature of $850{ }^{\circ} \mathrm{C}$ ) and respectively, to $11 \%$ (at $900{ }^{\circ} \mathrm{C}$ ). The tests performed only with graphite as a foaming agent showed that the closed porosity was predominant being around $80 \%$ regardless of the value of the foaming temperature. At the $\mathrm{CaCO}_{3} /$ graphite ratio $=2$ (corresponding to the optimal characteristics of the product presented above) the closed porosity reached about $31 \%\left(\right.$ at $850^{\circ} \mathrm{C}$ ) and $27 \%\left(\right.$ at $900{ }^{\circ} \mathrm{C}$ ).

\section{METHODS AND MATERIALS}

\subsection{Methods}

According to the basic principle mentioned above of the manufacture of glass foam by foaming glass waste, the foaming agents used in this experiment (graphite and $\mathrm{CaCO}_{3}$ ) incorporated in the powder mixture of raw material and additives release gases following oxidation and decomposition chemical reactions. The carbon contained in graphite reacts at temperatures between $600-750{ }^{\circ} \mathrm{C}$ with oxygen in the oxidizing atmosphere of the oven and in the spaces between the fine particles of the raw material according to the reactions (1) and (2).

$$
\begin{gathered}
\mathrm{C}+0.5 \mathrm{O}_{2}=\mathrm{CO} \\
\mathrm{C}+\mathrm{O}_{2}=\mathrm{CO}_{2}
\end{gathered}
$$


The released gaseous compounds are trapped in the viscous mass of the glass contributing to the foaming process. Under normal conditions of pressure and without the influence of other additives, the calcium carbonate decomposes according to the reaction (3) at over $900{ }^{\circ} \mathrm{C}[20,21]$ into $\mathrm{CaO}$ (solid), which is incorporated into the composition of molten glass and $\mathrm{CO}_{2}$ (gas), which is released into the viscous mass of the glass and participates in its foaming.

$$
\mathrm{CaCO}_{3}=\mathrm{CaO}+\mathrm{CO}_{2}
$$

The sodium borate addition as a fluxing agent as well as the high contents of $\mathrm{CaO}(12.0 \mathrm{wt} . \%)$ and $\mathrm{Na}_{2} \mathrm{O}(13.3$ wt.\%) in the glass composition decrease the melting temperature of glass. According to some own previous experiments [22] using $\mathrm{CaCO}_{3}$ and sodium borate, the sintering/foaming temperature of a soda-lime glass waste (commercial glass) was in the range $820-851^{\circ} \mathrm{C}$. In turn, $\mathrm{Na}_{2} \mathrm{HPO}_{4}$ introduced into the mixture together with carbon stabilized the produced glass foam.

As in the case of all tests performed in the last four years in the company Daily Sourcing \& Research, the experimental microwave equipment was a $0.8 \mathrm{~kW}$-oven of the type currently used in the household in food preparation, adapted for operation at high temperature (around $1200{ }^{\circ} \mathrm{C}$ ). The heating method adopted by the authors was mixed, predominantly direct and partially indirect by placing between the pressed sample (deposited freely on a metal plate) and the microwave emission source a ceramic tube of a high microwave-susceptible material based on silicon carbide and nitride (made in China) with an adequate thickness of its wall (2.5-3 mm). The tube allows both the direct irradiation of the sample by the penetration of the ceramic wall by waves and the partial absorption of the energy of microwave field in this wall, which heats up intensely and transfers heat by thermal radiation.

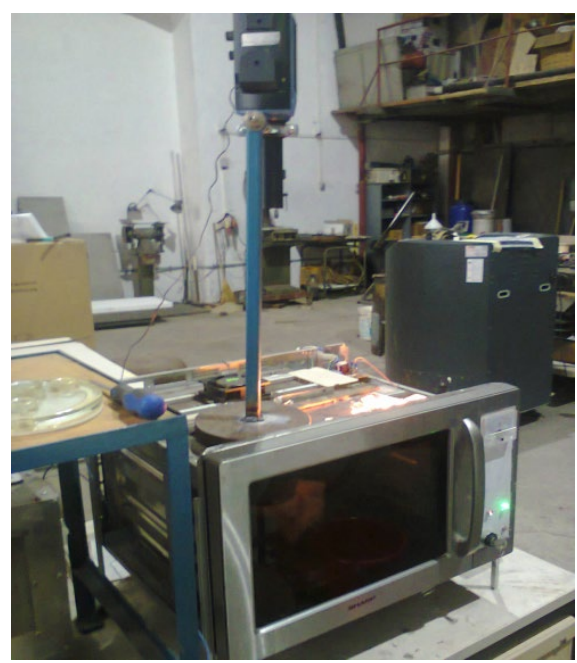

a

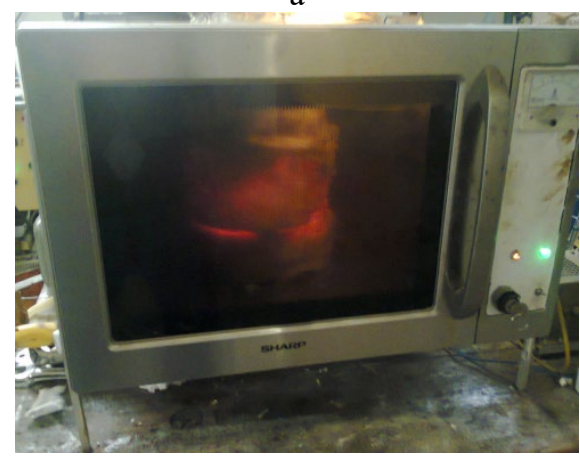

$\mathrm{c}$

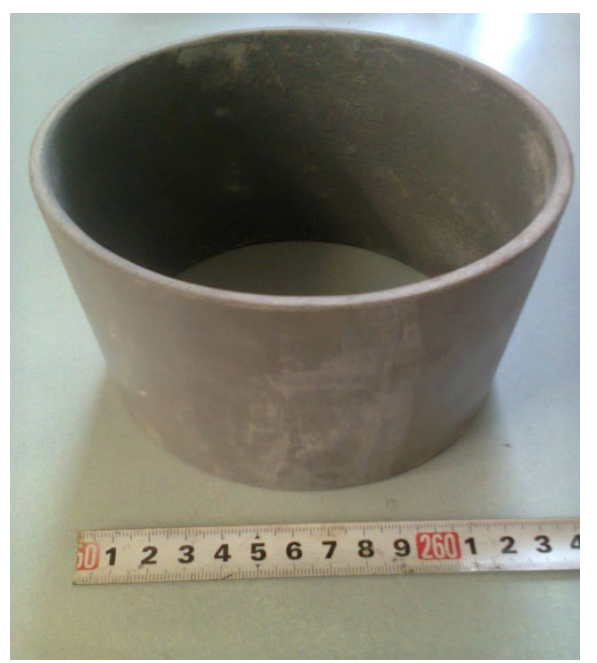

b

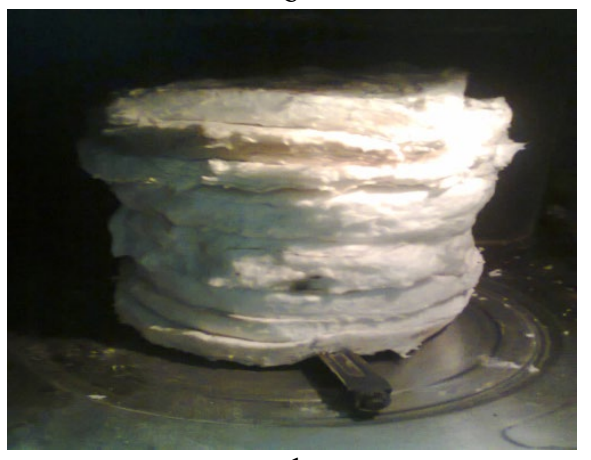

d

Fig. 1. The experimental microwave equipment: a - overall image of the equipment; $\mathrm{b}$ - ceramic tube; $\mathrm{c}-0.8$ $\mathrm{kW}$-microwave oven; $\mathrm{d}$ - ceramic fiber thermal insulation.

The main difference between the unconventional direct microwave heating and the conventional heating is the initiation of heating in the core of the irradiated material where the microwave energy is converted into heat and 
the maximum thermal level of the process is reached. The heat is propagated from the inside to the peripheral areas of the material, as opposed to the conventional heating. On the other hand, the heating is selective, so that only the irradiated material, which must have at least one component microwave susceptible, is efficiently heated, not the other constructive elements of the oven $[23,24]$. Therefore, the thermal insulation (with ceramic fiber mattresses) of the sample and the ceramic tube (including the ceramic lid that covers the upper opening of the tube) is a priority to avoid the heat loss outside the system. A Pyrovar type radiation pyrometer (measuring domain: $600-2000{ }^{\circ} \mathrm{C}$ ) mounted above the oven at $350-400 \mathrm{~mm}$ on the central vertical axis was used to control the temperature on the surface of the heated material. To view the material, the upper metal wall of the oven, the ceramic lid and the thermal insulation of the lid had provided $30 \mathrm{~mm}$-holes on the central axis. The experimental microwave equipment described above is shown in Figure 1.

\subsection{Materials}

The solid materials used in this experiment were: colorless post-consumer packaging bottle as raw material, graphite and calcium carbonate as foaming agents (simultaneously used), sodium borate as a fluxing agent and disodium phosphate as a foam stabilizing additive. The addition of sodium borate in combination with calcium carbonate having as an effect the increase of the final product compressive strength [22], excepting the increase of the molten mixture fluidity as well as the addition of disodium phosphate [18] in association with a carboncontaining foaming agent are manufacturing methods already applied in previous experiments of the authors.

The colorless post-consumer packaging bottle, with its chemical composition [25] shown in Table 1, based on the analysis carried out with an X-ray fluorescence spectrometer in the Metallurgical Research Institute Bucharest, was selected by color from the batch of glass waste, broken, ground into a ball mill and sieved, the grain size being below $100 \mu \mathrm{m}$. The glass waste processing was performed in the Romanian company Bilmetal Industries SRL Popesti-Leordeni. The graphite was purchased from the market in the form of natural flake graphite with an average carbon content of $90 \%$ and a grain size of $36 \mu \mathrm{m}$, being used in this state in the experiment. Purchased from the market at a grain size below $400 \mu \mathrm{m}$, the sodium borate was used in experiments below $120 \mu \mathrm{m}$ after the grinding in a laboratory electric device. Due to its high $\mathrm{Na}_{2} \mathrm{O}$ content, which is by far the most important fluxing material [26], especially, for the glass industry, the sodium borate was used in experiments as a fluxing agent. The calcium carbonate was used as a foaming agent without other mechanical processing such as it was purchased from the market having a very fine granulation below $15 \mu \mathrm{m}$. The disodium phosphate, a crystalline solid material, was purchased from the market with a grain size below $100 \mu \mathrm{m}$, being used in experiments as a foam stabilizing agent.

Table 1. Chemical composition of the colorless glass waste.

\begin{tabular}{|c|c|c|c|c|c|c|c|c|}
\hline $\mathrm{SiO}_{2}$ & $\mathrm{Al}_{2} \mathrm{O}_{3}$ & $\mathrm{CaO}$ & $\mathrm{Fe}_{2} \mathrm{O}_{3}$ & $\mathrm{MgO}$ & $\mathrm{Na}_{2} \mathrm{O}$ & $\mathrm{K}_{2} \mathrm{O}$ & $\mathrm{Cr}_{2} \mathrm{O}_{3}$ & $\mathrm{SO}_{3}$ \\
\hline 71.4 & 1.9 & 12.0 & 0.05 & 1.0 & 13.3 & 0.1 & 0.05 & 0.2 \\
\hline
\end{tabular}

\subsection{Characterization of the glass foam samples}

The determination of the physical, thermal, mechanical and morphological characteristics of the four glass foam samples was carried out using the following analysis techniques. The apparent density was measured by the gravimetric method [27] and the porosity was calculated by the comparing method of the true and apparent density [28]. The compressive strength was determined using a TA.XTplus Texture Analyzer (ASTM C552-17) and the thermal conductivity was measured by the heat-flow meter method (ASTM E1225-04) similar to the transient hot line method TC3000 of XIATECH Chinese technique [19]. The water absorption was determined by the water immersion for 24 hours method (ASTM D570). An ASONA 100X Zoom Smartphone Digital Microscope was used to investigate the microstructural configuration of the glass foam samples.

\subsection{Adoption of the experimental variants}

Four experimental variants were prepared according to Table 2. The weight ratio of the two foaming agents $\left(\mathrm{CaCO}_{3} /\right.$ graphite $)$ was varied having the following successive values: $0.9,1.6,2.2$ and 2.7 , approximately within the range of values tested in the paper [19]. The weight content of graphite was kept constant at 1 wt.\%.

Table 2. Experimental variants of glass foam samples.

\begin{tabular}{|c|c|c|c|c|c|c|}
\hline Variant & $\begin{array}{c}\text { Colorless } \\
\text { glass waste } \\
\text { wt.\% }\end{array}$ & $\begin{array}{c}\text { Sodium } \\
\text { borate } \\
\text { wt. } \%\end{array}$ & $\begin{array}{c}\text { Calcium } \\
\text { carbonate } \\
\text { wt. } \%\end{array}$ & $\begin{array}{c}\text { Graphite } \\
\text { wt. } \%\end{array}$ & $\begin{array}{c}\text { Disodium } \\
\text { phosphate } \\
\text { wt. } \%\end{array}$ & $\begin{array}{c}\text { Water } \\
\text { addition } \\
\text { wt.\% }\end{array}$ \\
\hline 1 & 89.1 & 3.0 & 0.9 & 1.0 & 6.0 & 10.0 \\
\hline 2 & 87.4 & 4.0 & 1.6 & 1.0 & 6.0 & 10.0 \\
\hline
\end{tabular}




\begin{tabular}{|l|l|l|l|l|l|l|}
\hline 3 & 85.7 & 5.0 & 2.2 & 1.0 & 6.1 & 10.0 \\
\hline 4 & 84.2 & 6.0 & 2.7 & 1.0 & 6.1 & 10.0 \\
\hline
\end{tabular}

\section{RESULTS AND DISCUSSION}

\subsection{Results}

As stated above, colorless post-consumer packaging bottle as raw material, graphite and calcium carbonate as foaming agents, sodium borate as a fluxing agent and disodium phosphate as a foam stabilizing additive were used as a dry powder mixture. A constant water weight proportion of $10 \%$ was added to facilitate the cold pressing of the powder mixture (Figure 2).

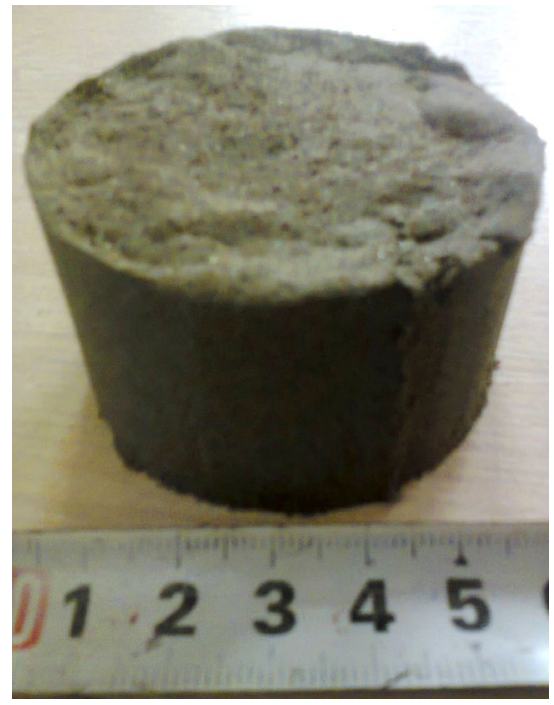

Fig. 2. Appearance image of the cold pressed powder mixture.

The experiments were performed on the adapted $0.8 \mathrm{~kW}$-microwave oven in the company Daily Sourcing \& Research. The dry powder mixture amount was kept constant for all variants at $485 \mathrm{~g}$. The monitored functional parameters of the manufacturing process were: sintering/foaming temperature, heating time, heating and cooling rate, index of volume growth and specific energy consumption. These parameters are presented in Table 3.

Table 3. The main functional parameters of the manufacturing process of glass foam.

\begin{tabular}{|c|c|c|c|c|c|c|c|}
\hline \multirow{2}{*}{ Variant } & \multirow{2}{*}{$\begin{array}{l}\text { Dry raw } \\
\text { material/ } \\
\text { glass foam } \\
\text { amount } \\
(\mathrm{g})\end{array}$} & \multirow{2}{*}{$\begin{array}{l}\text { Sintering/ } \\
\text { foaming } \\
\text { temperature } \\
\left({ }^{\circ} \mathrm{C}\right)\end{array}$} & \multirow{2}{*}{$\begin{array}{l}\text { Heating } \\
\text { time } \\
(\min )\end{array}$} & \multicolumn{2}{|c|}{$\begin{array}{l}\text { Average rate } \\
{ }^{\circ} \mathrm{C} / \mathrm{min}\end{array}$} & \multirow{2}{*}{$\begin{array}{l}\text { Index of } \\
\text { volume } \\
\text { growth }\end{array}$} & \multirow{2}{*}{$\begin{array}{c}\text { Specific } \\
\text { energy } \\
\text { consumption } \\
(\mathrm{kWh} / \mathrm{kg})\end{array}$} \\
\hline & & & & Heating & Cooling & & \\
\hline 1 & $485 / 471$ & 828 & 33 & 24.5 & 6.5 & 1.30 & 0.73 \\
\hline 2 & $485 / 470$ & 834 & 34.5 & 23.6 & 6.7 & 1.60 & 0.76 \\
\hline 3 & $485 / 473$ & 840 & 36 & 22.8 & 6.6 & 1.90 & 0.79 \\
\hline 4 & $485 / 472$ & 847 & 37.5 & 22.1 & 6.8 & 2.20 & 0.83 \\
\hline
\end{tabular}

By increasing the content of $\mathrm{CaCO}_{3}$ (from 0.9 to $2.7 \mathrm{wt} \%$ ) and sodium borate (from 3 to 6 wt.\%) and maintaining constant the graphite content (1 wt.\%) and disodium phosphate content (6-6.1 wt.\%) it was observed the increase of the sintering/foaming temperature process from 828 to $847^{\circ} \mathrm{C}$ and implicitly, the heating time from 33 to $37.5 \mathrm{~min}$. The energy efficiency of the predominantly direct and partially indirect microwave heating process was remarkable, the value of specific energy consumption being between $0.73-0.83 \mathrm{kWh} / \mathrm{kg}$, the lowest value corresponding to the ratio of foaming agents of 0.9 (variant 1) and the highest corresponding to the ratio of 2.7 (variant 4).

The main physical, thermal, mechanical and microstructural characteristics of glass foam samples are presented in Table 4 . 
Table 4. Physical, thermal, mechanical and microstructural characteristics of the glass foam samples.

\begin{tabular}{|c|c|c|c|c|c|c|}
\hline Variant & $\begin{array}{c}\text { Apparent } \\
\text { density } \\
\left(\mathrm{g} / \mathrm{cm}^{3}\right)\end{array}$ & $\begin{array}{c}\text { Porosity } \\
(\%)\end{array}$ & $\begin{array}{c}\text { Thermal } \\
\text { conductivity } \\
(\mathrm{W} / \mathrm{m} \cdot \mathrm{K})\end{array}$ & $\begin{array}{c}\text { Compressive } \\
\text { strength } \\
(\mathrm{MPa})\end{array}$ & $\begin{array}{c}\text { Water } \\
\text { absorption } \\
(\%)\end{array}$ & $\begin{array}{c}\text { Pore size } \\
(\mathrm{mm})\end{array}$ \\
\hline 1 & 0.39 & 81.4 & 0.088 & 3.6 & 3.5 & $0.10-0.20$ \\
\hline 2 & 0.34 & 83.8 & 0.071 & 3.0 & 3.3 & $0.20-0.50$ \\
\hline 3 & 0.28 & 86.7 & 0.069 & 2.1 & 3.0 & $0.40-0.80$ \\
\hline 4 & 0.26 & 87.6 & 0.060 & 1.1 & 2.8 & $0.60-0.90$ \\
\hline
\end{tabular}

Analyzing the data in Table 4, it is generally noted the thermal insulation characteristics of all samples manufactured by this experiment. Values of apparent density between $0.26-0.39 \mathrm{~g} / \mathrm{cm}^{3}$, thermal conductivity between $0.060-0.088 \mathrm{~W} / \mathrm{m} \cdot \mathrm{K}$, porosity within the limits of $81.4-87.6 \%$ and compressive strength between 1.1 3.6 $\mathrm{MPa}$ are acceptable for several application fields of glass foams. The characteristics of sample 4 are recommended for interior or exterior thermal insulation boards or panels of buildings without mechanical stress. The characteristics of samples 2 and 3 would be indicated for thermal insulation panels of the outer walls of buildings that require a high strength to mechanical stress. Sample 1 has the optimal characteristics of a foam glass gravel [10] usable for interior or exterior thermal insulation of basements and rooftops, lightweight filling material for landscaping, roof gardens, green roofs, drainages, road and railway constructions, bridge abutments, insulation of underground pipelines or storage tanks, etc.

An important role in determining the efficiency of a thermal insulation material has the homogeneity of the porous structure, the size and uniformity of the pores and the type of porosity (closed or open). Therefore, the microstructural configuration of the samples was examined (Figure 3).

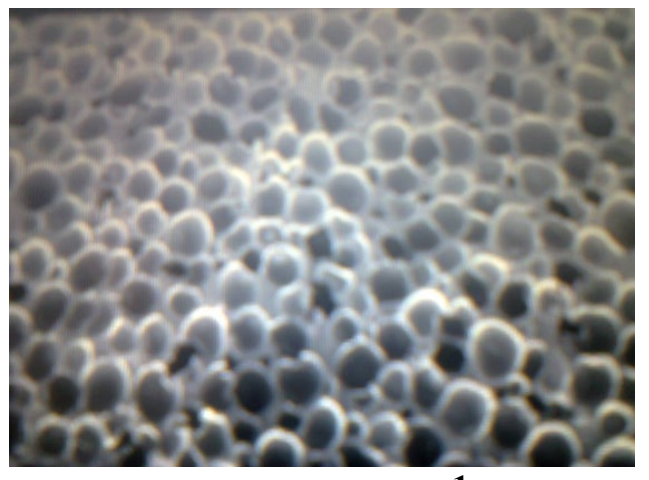

a

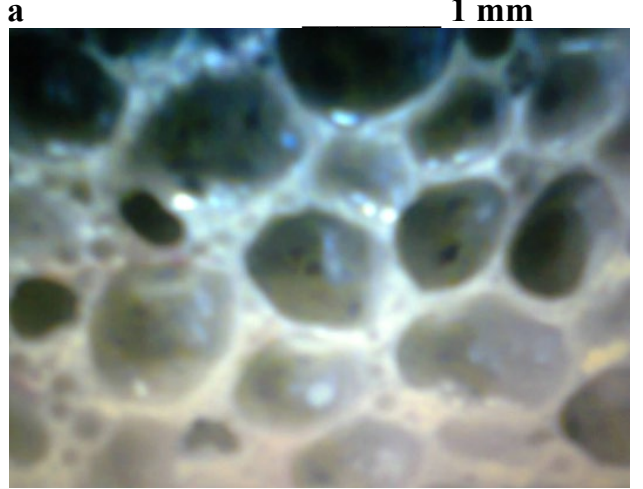

c

$1 \mathrm{~mm}$

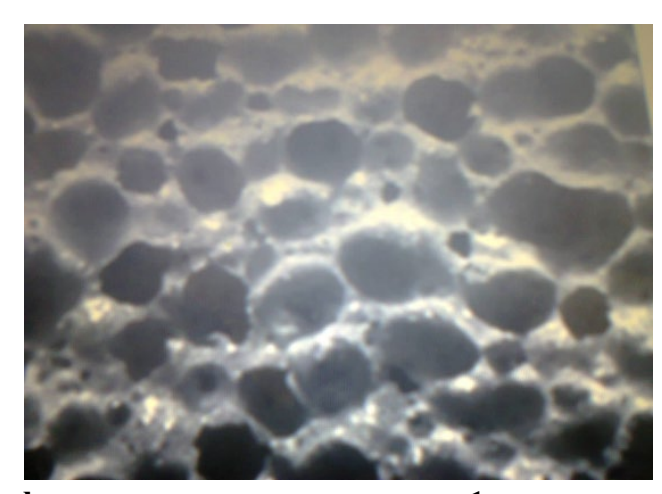

b

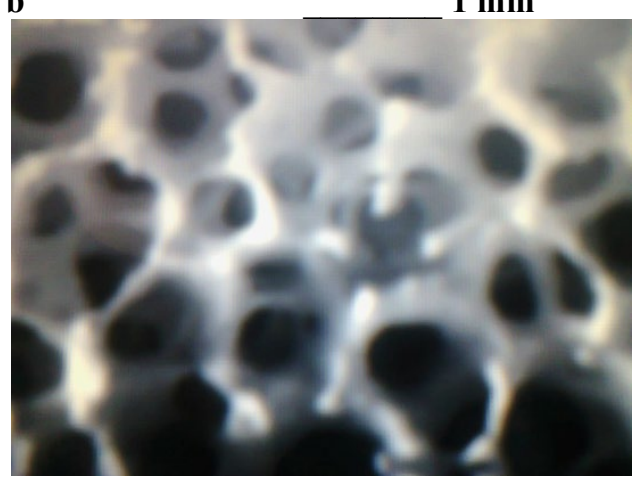

d

$1 \mathrm{~mm}$

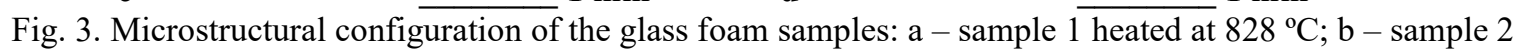
heated at $834^{\circ} \mathrm{C}$; c - sample 3 heated at $840^{\circ} \mathrm{C}$; d - sample 4 heated at $847^{\circ} \mathrm{C}$.

The tendency to form a semi-open porous structure by creating intercommunications between the cells of the material at higher weight ratios of the two foaming agents $\left(\mathrm{CaCO}_{3}\right.$ and graphite) was also observed recently by Liu at al. [19]. In Figure 3d (variant 4) this phenomenon is clearly visible under a microscope and corresponds to the ratio of 2.7. In Figure 3c (variant 3 ) with a ratio of 2.2, only a very insignificant beginning of the formation of intercommunication between cells is visible. The other microstructures (variants 1 and 2) show closed porous 
structures with very small pore sizes (between $0.10-0.20 \mathrm{~mm}$ and between $0.20-0.50 \mathrm{~mm}$, respectively). In this experiment, no determinations of the ratio of closed and open pores could be made. According to [19], the use of ratios between $\mathrm{CaCO}_{3}$ and graphite of $1: 1 ; 2: 1$ and $3: 1$ (wt.\%) led to the formation of structures with open porosity of 51,70 and $78 \%$, respectively (at $850^{\circ} \mathrm{C}$ ). Usually, a glass foam with open porosity is usable as filters, absorbers, gas sensors, sound insulations [3], but the open porosity must be very high (85-100\%).

\subsection{Discussion}

The present research demonstrated once again the remarkable energy efficiency of predominantly direct microwave heating, the specific energy consumption being between $0.73-0.83 \mathrm{kWh} / \mathrm{kg}$, i.e. at a level at least comparable to that of conventional industrial processes.

According to the literature [29], the usual commercial glass (soda-lime glass), which is the largest waste glass in the world, has in its composition relatively high concentrations of oxides of alkali metals (especially $\mathrm{Na}_{2} \mathrm{O}$ and $\mathrm{K}_{2} \mathrm{O}$ ). These compounds favor the microwave heating due to their high electrical conductivity, which facilitates the absorption of electromagnetic waves. Also, the presence of sodium borate as a fluxing agent in the starting powder mixture contributes to increasing the efficiency of microwave heating due to its $\mathrm{Na}_{2} \mathrm{O}$ content [26].

The presence, even in very small proportions of $\mathrm{Fe}_{2} \mathrm{O}_{3}$ and $\mathrm{Cr}_{2} \mathrm{O}_{3}$, inherent contaminants with high microwave susceptibility in the soda-lime glass composition, contributes to the initiation of the heating process with high efficiency since room temperature. This is because these compounds absorb electromagnetic radiations more efficiently at this temperature [23], unlike $\mathrm{SiO}_{2}, \mathrm{Al}_{2} \mathrm{O}_{3}$, major components in the glass composition that are not microwave susceptible at low temperature.

Analyzing the physical, thermal, mechanical and morphological characteristics of the foamed products manufactured in this experiment it was concluded that the optimal product should be chosen from variants 1 and 2, whose microstructures presented closed porosity. Considering the highest compressive strength (3.6 MPa), remarkable structural homogeneity and relatively low apparent density $\left(0.39 \mathrm{~g} / \mathrm{cm}^{3}\right)$, the sample obtained by experimental variant 1 was adopted as the optimal sample, having characteristics at the level of very good industrially manufactured foam glass gravels. In addition, the specific energy consumption of the manufacturing process was the most economical $(0.73 \mathrm{kWh} / \mathrm{kg})$ of the four experimental variants.

\section{CONCLUSIONS}

The aim of the paper was to experimentally make a glass foam with high mechanical strength using the combination of two solid foaming agents: a carbonate $\left(\mathrm{CaCO}_{3}\right)$ and a carbonic material (graphite) in a variable weight ratio.

The microwave energy converted into heat was adopted as an energy source and this advanced method is the originality of the work, unlike the conventional heating technique currently used in the world in similar industrial or experimental processes.

Four experimental variants were designed, in which the $\mathrm{CaCO}_{3} /$ graphite ratio was varied between 0.9 and 2.7 keeping constant the weight proportion of graphite at $1 \mathrm{wt} \%$. Also, additives with fluxing role (sodium borate) and foam stabilizing role $\left(\mathrm{Na}_{2} \mathrm{PO}_{4}\right)$ were added to the dry mixture finely ground, wetted and pressed.

The sintering/foaming temperature of the mixture had values between $828-847^{\circ} \mathrm{C}$, the average heating rate being high $\left(22.1-24.5^{\circ} \mathrm{C} / \mathrm{min}\right.$ ), unlike the conventional heating techniques (heating rate of around $10^{\circ} \mathrm{C} / \mathrm{min}[19]$ ).

The experimental results showed that variating the ratio of the two foaming agents it can obtain foamed products with very different mechanical strength from 1.1 to $3.6 \mathrm{MPa}$ and with suitable thermal insulation properties (apparent density between $0.26-0.39 \mathrm{~g} / \mathrm{cm}^{3}$, thermal conductivity between $0.060-0.088 \mathrm{~W} / \mathrm{m} \cdot \mathrm{K}$ and porosity between $81.4-87.6 \%$ ). In the case of the ratio between the two foaming agents with values above 2.2 , the formation tendency of semi-open porous structures by the intercommunication between the material cells was observed. At the maximum value of the ratio (2.7) the semi-open porous structure was evident by examination with the microscope. This type of microstructure has contributed to the decrease of the compressive strength up to $1.1 \mathrm{MPa}$. 
The optimal variant with closed and very homogeneous microstructure was variant 1 composed of 0.9 wt. $\%$ $\mathrm{CaCO}_{3}, 1$ wt.\% graphite, 3 wt.\% sodium borate, 6 wt.\% $\mathrm{Na}_{2} \mathrm{HPO}_{4}, 89.1$ wt.\% colorless post-consumer packaging glass and $10 \mathrm{wt} . \%$ water addition. The sintering/foaming temperature was $828^{\circ} \mathrm{C}$. The product characteristics were: apparent density of $0.39 \mathrm{~g} / \mathrm{cm}^{3}$, thermal conductivity of $0.088 \mathrm{~W} / \mathrm{m} \cdot \mathrm{K}$, porosity of $81.4 \%$, compressive strength of $3.6 \mathrm{MPa}$, water absorption of $3.5 \%$ and pore size between $0.10-0.20 \mathrm{~mm}$.

The specific energy consumption was very low $(0.73 \mathrm{kWh} / \mathrm{kg})$ being at the level of similar conventional industrial processes.

In terms of quality, the optimal foamed product has the characteristics of a foam glass gravel industrially manufactured from glass waste by conventional techniques, usable as a thermal insulation material in application fields that requires resistance to mechanical stress and relatively difficult environmental conditions (variable temperatures, humidity, etc.).

\section{REFERENCES}

[1] https://www.archive.epa.gov/oswer/international/web/html/byproducts-guidance-053007.html (22.02.2021).

[2] Rodriguez Vieitez, E., Eder, P., Villanueva, A., Saveyn, H., End-of-waste criteria for glass cullet: Technical proposals, EUR 25220 EN Publication Office of the European Union, Luxembourg, 2011.

[3] Paunescu, L., Grigoras, B.T., Dragoescu, M.F., Axinte, S.M., Fiti, A., Foam glass produced by microwave heating technique, Bulletin of Romanian Chemical Engineering Society, vol. 4, no. 1, 2017, p. 98-108.

[4] da Silva, L.L., Nunes, R.L.C., Santacruz, G., Arcaro, S., Koop, A.A., Pérez, B.C., Glass foams produced from glass and yerba mate (Ilex paraguarinensis), FME Transactions, vol. 46, 2016, p. 70-79.

[5] Paunescu, L., Dragoescu, M.F., Axinte, S.M., Fiti, A., Innovative way to produce glass foam in microwave field, Nonconventional Technologies Review, vol. 22, no. 3, 2018, p. 21-25.

[6] Scarinci, G., Brusatin, G., Bernardo, E., Glass foams, in cellular ceramics: structure, manufacturing, properties and applications, Ed. Wiley-VCH GmbH and KGaA, Weinheim, Germany, 2005, p. 158-176.

[7] Fernandes, H.R., Tulyaganov, D.U., Ferreira, J.M.F., Preparation and characterization of foams sheet glass and fly ash using carbonates as foaming agents, Ceramics International, vol. 35, no. 1, 2009, p. 229-235.

[8] Petersen, R.R., Koning, J., Smedskjaer, M.M., Yue, Y., Foaming of CRT panel glass powder using $\mathrm{Na}_{2} \mathrm{CO}_{3}$, Glass Technology: European Journal of Glass Science and Technology, Part A, vol. 55, no. 1, 2014, p. 1-6.

[9] Lv, D.S., Li, X.H., Wang, J., Zhang, J., Effect of carbon as foaming agent on pore structure of foam glass, Advanced Materials Research, vol. 105, no. 1, 2010, p. 765-768.

[10] Cosmulescu, F., Paunescu, L., Dragoescu, M.F., Axinte, S.M., Comparative analysis of the foam glass gravel types experimentally produced by microwave irradiation, Journal of Engineering Studies and Research, vol. 26, no. 3, 2020, p. 58-68.

[11] Karandashova, N.S., Goltsman, B.M., Yatsenko, E.A., Analysis of influence of foaming mixture components on structure and properties of foam glass, IOP Conf. Series: Materials Science and Engineering, vol. 262, 2017, p. 1-6.

[12] Ostergaard, M.B., Petersen R.R., Konig, J., Yue, Y. Effect of alkali phosphate content on foaming of CRT panel glass using $\mathrm{Mn}_{3} \mathrm{O}_{4}$ and carbon as foaming agents, Journal of Non-Crystalline Solids, vol. 482, 2018, p. 217-222.

[13] Konig, J., Petersen, R.R., Yue, Y., Influence of the glass-calcium carbonate mixture's characteristics on the foaming process and the properties of the foam glass, Journal of the European Ceramic Society, vol. 34, no. 6, 2014, p. 1591-1598.

[14] Konig, J., Petersen, R.R., Yue, Y., Fabrication of highly insulating foam glass made from CRT panel glass, Ceramics International, vol. 41, no. 8, 2015, p. 9793-9800.

[15] Dragoescu, M.F., Axinte, S.M., Paunescu, L., Fiti, A., Foam glass with low apparent density and thermal conductivity produced by microwave heating, European Journal of Engineering and Technology, vol. 6, no. 2, 2018, p. 1-9.

[16] Axinte, S.M., Paunescu, L., Dragoescu, M.F., Sebe, A.C., Manufacture of glass foam by predominantly direct microwave heating of recycled glass waste, Transactions on Networks and Communications, vol. 7, no. 4, 2019, p. 37-45.

[17] Kharissova, O., Kharissov, B.I., Ruiz Valdés, J.J., Review: The use of microwave irradiation in the processing of glasses and their composites, Industrial and Engineering Chemistry Research, vol. 49, no. 4, 2010, p. $1457-1466$.

[18] Paunescu, L., Dragoescu, M.F., Axinte, S.M., Sebe, A.C., Glass foam from borosilicate glass waste produced in microwave field, Nonconventional Technologies Review, vol. 23, no. 1, 2019, p. 8-12. 
[19] Liu, Y., Xie, J., Hao, P., Shi, Y., Xu, Y., Ding, X., Study on factors affecting properties of foam glass made from waste glass, Journal of Renewable Materials, vol. 9, no. 2, 2021, p. 237-252.

[20] Karunadasa, K.S.P., Manoratne, C.H., Pitawala, H.M.T.G.A., Rajapakse, R.M.G., Thermal decomposition of calcium carbonate (calcite polymorph) as examined by in-situ high-temperature X-ray powder diffraction, Journal of Physics and Chemistry of Solids, vol. 134, 2019, p. 21-28.

[21] Ducman, V., Foaming process of waste glass using $\mathrm{CaCO}_{3}, \mathrm{MnO}_{2}$ and water glass as foaming agents, International Conference "Sustenable waste management and recycling. Glass waste", London, 2004.

[22] Paunescu, L., Dragoescu, M.F., Axinte, S.M., Paunescu, B.V., Dense glass foam produced in microwave field, Journal of Engineering Studies and Research, vol. 24, no. 1, 2018, p. 30-36.

[23] Jones, D.A., Lelyveld, T.P., Mavrofidis, S.D., Kingman, S.W., Miles, N.J., Microwave heating applications in environmental engineering-a review, Resources, Conservation and Recycling, vol. 34, no. 2, 2002, p. 75-90.

[24] Kitchen, H.J., Vallance, S.R., Kennedy, J.L., Tapia-Ruiz, N., Carassiti, L., Harrison, A., Whittaker, A.G., Drysdale, T.D., Kingman, S.W., Gregory, D.H., Modern microwave methods in solid-state inorganic materials chemistry: from fundamentals to manufacturing, Chemical Reviews, vol. 114, no. 2, 2014, p. 1170-1206.

[25] Dragoescu, M.F., Paunescu, L., Axinte, S.M., Fiti, A., Influence of the color of bottle glass waste on the characteristics of foam glass produced in microwave field, International Journal of Science and Engineering Investigations, vol. 7, no. 72, 2018, p. 95-100.

[26] Bray, C., Dictionary of glass: materials and techniques, Second edition, University of Pennsylvania Press, Philadelphia, 2001. 